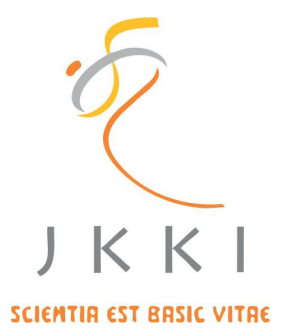

Jurnal Kedokteran dan Kesehatan Indonesia

Indonesian Journal of Medicine and Health

Journal homepage: https://journal.uii.ac.id/JKKI

\title{
Histopathological changes in liver, kidney and teratogenic effects of mice on exposure to mosquito repellent
}

Desy Armalina*1, Bambang Witjahjo ${ }^{1}$, and Neni Susilaningsih ${ }^{1}$

${ }^{1}$ Department of Histology, Faculty of Medicine, Universitas Diponegoro, Semarang, Indonesia

Original Article

\begin{tabular}{l}
\hline \\
\hline ART ICLE I NF O \\
\hline Keywords: \\
D-Allethrin, \\
Liver, \\
Kidney, \\
Teratogenic, \\
Foetus \\
\hline *Corresponding author: \\
desy.armalina@gmail.com \\
\hline DOI: $10.20885 / J K K I . V o l 12 . I s s 1 . a r t 4$ \\
\hline History: \\
Received: January 29, 2019 \\
Accepted: December 28, 2020 \\
Online: April 30, 2021 \\
\hline Copyright @2021 Authors. \\
This is an open access article \\
distributed under the terms \\
of the Creative Commons At- \\
tribution-NonCommercial 4.0 \\
International Licence (http:// \\
creativecommons.org/licences/ \\
by-nc/4.0/).
\end{tabular}

ABSTRACT

Background: Mosquito repellent technology has changed from conventional technology to electric technology, which is more secure and practical. All insect repellent contains chemical compounds that can endanger health. D-Allethrin, the first pyrethroid generation of mosquito repellent is used commercially. Some studies in multi-ethnic population found transplacental transmission in pregnancy.

Objective: This study aims to evaluate influences of D-Allethrin in mosquito repellent on liver and kidney, and teratogenic effects in foetal mice.

Methods: An experimental laboratory design was conducted in 18 pregnant female Balb/c mice. They were randomized into 3 groups: Group K, P1 and P2. Group K was not given anything. Group P1 and P2 were given exposure pathways of mosquito repellent with inhalation for 12 and 24 hours, in a period of gestational age (0-18 days). On day 19, a Cesar surgery was conducted to take their foetuses and to count the number of living foetuses, dead foetuses, disability, and morphological abnormalities. Results: The administration of allethrin inhalation with dose 12 hours and 24 hours significantly damage mice's kidney and liver microscopically $(p<0.05)$. A microscopic result of the liver were necrosis in portal areas, hydropic degeneration of lobules, infiltration of inflammatory cells, and fibrosis in the portal area causing a sinusoidal portal to widen. Kidney examination obtained necrosis and hydropic degeneration, as well as the infiltration of lymphocytes and erythrocytes. Teratogenic effects in the foetuses were prematurity and failure of foetal development.

Conclusion: Exposure pathways of D-Allethrin in mosquito repellent affected the microscopic appearance of the liver, kidney, and teratogenic effects in the foetuses.

Latar Belakang: Teknologi pengusir nyamuk memiliki perubahand dari penggunaan alat konvensional ke alat yang lebih aman dan praktis yaitu elektrik. Semua pengusir serangga mengandung senyawa kimia yang membahayakan kesehatan. D-Allethrin, adalah generasi piretroid pertama pengusir nyamuk yang digunakan secara komersial. Penelitian dalam populasi multietnis menemukan penularan transplacental pada kehamilan.

Tujuan: Tujuan penelitian ini yaitu untuk mengevaluasi pengaruh D-Allethrin sebagai pengusir nyamuk pada gambaran mikroskopik hati dan ginjal, serta efek teratogenik pada janin mencit.

Metode: Desain eksperimental dilakukan pada 18 mencit Balb/c betina hamil. Mereka diacak menjadi 3 kelompok. Grup K tidak diberikan apa-apa. Kelompok P1 dan P2 diberikan paparan inhalasi selama 12 dan 24 jam, pada periode usia kehamilan 0-18 hari. Pada hari ke-19, operasi Cesar dilakukan untuk mengambil 
janin, menghitung jumlah janin yang hidup, janin mati, cacat, dan kelainan morfologis.

Hasil: Pemberian allethrines secara inhalasi dengan dosis 12 dan 24 jam signifikan merusak gambaran miksoskopik ginjal dan hati mencit ( $p<0.05)$. Hasil mikroskopis hati terdapat nekrosis di area portal, hydropic degenerasi lobules, infiltrasi sel-sel inflamasi, serta fibrosis di area portal yang menyebabkan sinusoidal area portal melebar. Pemeriksaan ginjal diperoleh nekrosis dan hydropic degenerasi, serta infiltrasi limfosit dan eritrosit. Efek teratogenik pada fetuses adalah adanya prematuritas dan kegagalan perkembangan janin.

Kesimpulan: Paparan D-Allethrin pada pengusir nyamuk mempengaruhi gambaran mikroskopik hati, dan ginjal, serta berefek teratogenik pada janin.

\section{INTRODUCTION}

Vector-borne diseases are distributed across infections between vectors and hosts. These diseases are a worldwide fear and a major cause of human morbidity and mortality. The vectors consist of mosquitoes, flies, cockroaches, and fleas, but hosts are often humans or other animals. ${ }^{1}$ Indonesia is the largest tropical country in the world so that mosquito vectors can grow rapidly. The vectors can cause an increase of morbidity and mortality rates that are high enough and potentially lead to an extraordinary event. ${ }^{2}$ There are 1.3 billion people in the world who are at risks of infecting infected lymphatic filariasis/elephantiasis in more 83 countries, and $60 \%$ of the cases are in Southeast Asia. In Indonesia, there were 12,677 cases of filariasis in 2017, and the number of dengue haemorrhagic fever (DHF) patients was reported as many as 68,407 cases with a total number of deaths of 493 people. For malaria cases, nationally in 2017, malaria morbidity rates were 0.99 per 1,000 population. ${ }^{2}$

Expanded uses of insecticides in homes for pest control can have risks of indoor exposure pathways of these compounds. Spraying of insecticides at high levels has been suggested as an emergency vector-control practice during outbreaks of mosquito-borne diseases such. dengue fever in subtropical countries. Nevertheless, this practice may cause significant exposure pathways for humans. In the meantime, modern houses are often designed to be more airtight associated with stronger construction to improve energy effectiveness. The modern houses are managed to have lesser ventilation rates, which can reduce dispersion of indoor pollutants, leading risks of indoor exposure pathways. ${ }^{3}$

Insecticides that are widely used in the world are cyanotic groups containing pyrethroid which is made from extracts of Chrysanthemum cinerarifolium flower. ${ }^{4}$ Synthetic pyrethroids have been declared safer than the previous group of insecticide, organochlorines, and organophosphates because it is more selective towards the target. ${ }^{5}$ Compared to old-style pesticides, pyrethroid pesticides are less probable to pollute the environment, but they can enter organisms over of food chains in the ecosystem. Synthetic pyrethroids are broadly used as active compounds of mosquito repellent due to their relatively low toxicity to mammals. ${ }^{6}$ Meanwhile, recent studies showed that pyrethroids might cause behavioural and developmental neurotoxicity, with special concerned risks for infants and children, due to their potential exposures during a sensitive neurodevelopmental stage. Besides, some pyrethroids are listed as endocrine disruptors and possible carcinogens. ${ }^{3}$ Because of lipophilicity of pyrethroids, it is hard to eliminate them once they insert an organism. Longstanding, low-dose contact to pyrethroids can cause chronic diseases and have toxic effects on the nervous, immune, cardiovascular, and genetic systems of organisms, inducing teratogenicity, carcinogenicity, and mutagenicity. ${ }^{7}$ In 2015 , pesticides were measured in carpet dust from houses of 277 children with leukaemia and 306 controls of childrens in northern and central California, United States, where pyrethroid residues were resulting from home and garden pest actions. Among individuals, $94 \%$ of cases and $92 \%$ of controls had sufficient dust. ${ }^{8}$

The first pyrethroid group, which was used commercially and identified since 1949 , is Allethrin. Allethrin has been extensively used 
to exterminate mosquitoes and flies. It is used in thoroughly all brands of mosquito coils in South Asian territory. ${ }^{9}$ However, a study in Saudi Arabia showed histopathological damage to liver, lung, kidney, brain, and heart, exposed by coils, mats, and liquids mosquito repellent contains allethrin. ${ }^{4}$ Chronic exposure pathways of allethrin may produced in developmental neurotoxicity and nigrostriatal dopaminergic neurodegeneration, so favouring Parkinson's disease and other neurodegenerative diseases. ${ }^{10}$

A previous study stated that pesticides might pass through the placenta and accumulate in a foetal central nervous system, which can cause damage to the foetal neurodevelopment or induce formation of childhood brain tumours. ${ }^{11}$ Other studies on pregnant women in China and the U.S. found associations of urinary and inhalation pyrethroid concentrations to poorer mental development in infants and toddlers, meanwhile, in Canada and the U.S. it was found higher pyrethroid concentrations in urine and some behavioural problems in school-age children. ${ }^{12,13}$ This study aims to assess effects of D-Allethrin inhalation on microscopic description of Balb/c pregnant female mice's liver and kidney and the teratogenic effect on its foetus.

\section{METHODS}

\section{Research Design}

This study was a laboratory experimental research conducted at the Department of Histology, Faculty of Medicine, Universitas Diponegoro, at the Faculty of Mathematics and Natural Sciences, Universitas Negeri Semarang, and at the Department of Anatomic Pathology, Faculty of Medicine Universitas Diponegoro within 6 months. Study ethics of this study was approved by the Research Ethics Committee of Faculty of Medicine, Universitas Diponegoro/ Dr. Kariadi Semarang Hospital, No.477/EC/ FK/RSDK/2013.

\section{Statistical analysis}

All obtained data in this study were processed with the SPSS computer program,
The data was measured with a Shapiro-Wilk test and followed by Mann Whitney Test.

\section{Subjects and treatment of study}

Subjects of this study were 18 female mice of Balb /C strain with 8-10 weeks of age, 25 to 35 grams of weight, health condition, and without anatomical abnormalities. Each of three female mice was caged together with 1 male for 12 hours, from 18:00 to 6:00 am. Day 0 of pregnancy was determined by presence of a vaginal plug. ${ }^{14,15}$ All pregnant mice were divided into 3 groups. Each group consisted of 6 mice that were randomly chosen and then acclimatized for 7 days. The control group was not given any treatment, and the P1 and P2 treatment groups were given an electric mosquito-repellent liquid containing D-Allethrin exposure of $5.9 \% \mathrm{w} / \mathrm{w}$ inhalation with P1(12 hours) and P2 (24 hours) during pregnancy. Since the beginning of the treatment, an observation had been conducted on aggressiveness of mice, their activities in the daytime and their fights with other mice in one cage, ambulated easily about the cage, took interest in its environment, interacted with its cage mates. Thus activities was observed until the $18^{\text {th }}$ day of pregnancy. ${ }^{16}$

\section{Histopathological examination}

On the $19^{\text {th }}$ day, a caesarean-section was performed to observe the teratogenic effects of mice's foetus and termination of pregnant mice with anesthesia follow by cervical dislocation for an examination of microscopic preparations on liver and kidney. For teratogenic effects, an observation was conducted on the frequency of absorbed and lived foetuses in each mice, external malformation changes between the control (abnormality in the foetuses).

The livers and kidneys of mice were processed micro-technically and stained by using haematoxylin and eosin (HE). Each preparation was read at 5 fields of view and analysed by using a microscope to evaluate their histopathological index. The Knodell score was used for the liver score to find out degeneration in lobules, inflammatory cell infiltration, and 
fibrosis at the portal area, while the and kidneys preparation reading was using histopathology score to find necrosis, degeneration and infiltration in lymphocyte and erythrocyte of mice's kidneys. ${ }^{17,18}$

All obtained data in this study were processed with the SPSS computer program. To see the effect of allethrin exposure to mice's kidney and liver, the Mann-Whitney U test were performed.

\section{RESULTS}

\section{Maternal Observation}

Results of observation on condition of the mice during the treatment showed that there was aggressiveness of the mice during their activities in the daytime and their fights with other mice in one cage. The aggressiveness of mice that received 24-hour inhalation treatment was greater than of mice with 12 -hour treatment. There was a significant difference in kidney damage compared to the control group, and there was significantly worse damage at longer exposure (24 hours) (Table 1). Histopathology slide found necrosis and degeneration especially hydropic degeneration and infiltration in lymphocyte and erythrocyte at the longer exposures in the microscopic description of mice's kidneys (Figure1).

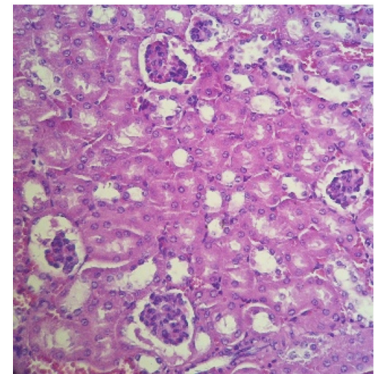

Group K

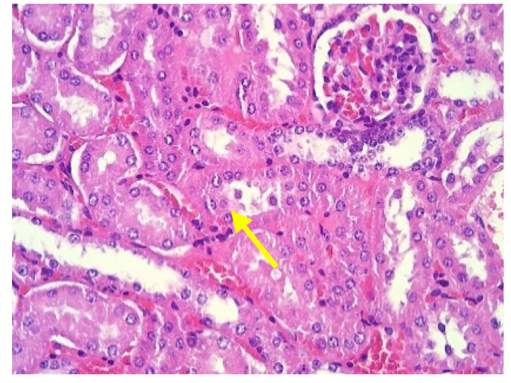

Group P12

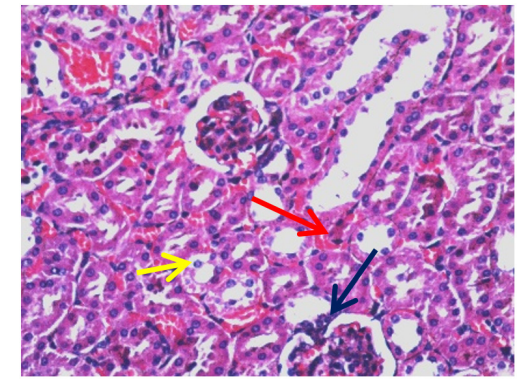

Group P24

Figure 1. Histopathological kidney result.

Yellow: hydropic degeneration,

Orange Arrow: necrosis,

Blue arrow: lymphocyte and erythrocyte infiltration. 400x, HE

Table 1. Kidneys and liver damage index

\begin{tabular}{lccc}
\hline \multicolumn{1}{c}{ Group } & Mean+SD & P12 & P24 \\
\hline Kidney & & & \\
Control & $1+0.0$ & $0.002^{*}$ & $0.002^{*}$ \\
12-hour treatment (P12) & $3.0+0.9$ & & $0.015^{*}$ \\
24-hour treatment (P12) & $4.5+0.5$ & & \\
Liver & & & \\
Control & $1+0.0$ & $0.002^{*}$ & $0.002^{*}$ \\
12-hour treatment & $6,8+1.6$ & & $0.009^{*}$ \\
24-hour treatment & $9,5+1.6$ & & \\
\hline *Significant $(p<0.05)$ & & &
\end{tabular}

*Significant $(\mathrm{p}<0.05)$

According to Figure 1 there was a significant difference in liver damage compared to the control group. There was significantly worse damage at longer exposure (24 hours). In the histopathological appearance, necrosis of the portal area was found in mice's livers, 


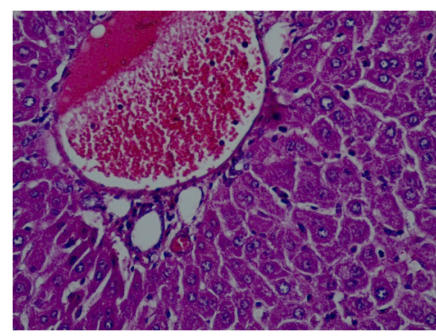

Group K

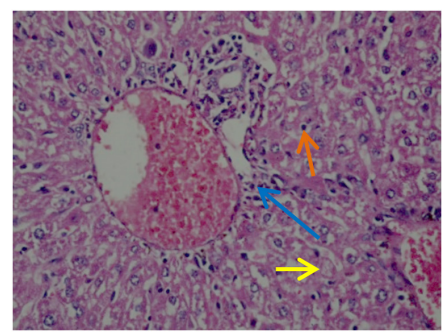

Group P12

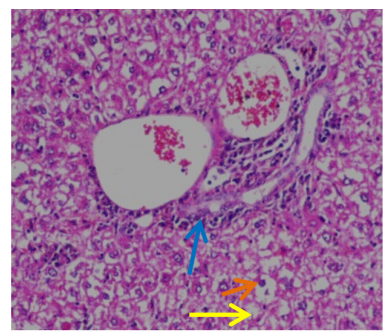

Group P24

Figure 2. Histopathological Liver Result Yellow Arrow: Hidropic degeneration, Orange Arrow: necrosis, Blue arrow: lymphocyte infiltration. 400x, HE

especially hydropic degeneration in lobules and inflammatory cell infiltration, as well as fibrosis starting at the portal area which caused sinusoids to expand at longer exposures (Tables 1).

\section{Foetus Observation}

Observation during termination that foetuses of mice in the control group without treatment had an average of 9 foetuses from 1 parent. In the group with 12 and 24-hour exposure, there was a failure in foetal development, as indicated by presence of black spots on the uterus, namely foetal resorption. Even though the abdomen was enlarged at the beginning of pregnancy, foetus was not found when a c-section was conducted, except P2-6 which showed prematurity foetuses, which were born alive before the 18th day as many as 4 foetuses with no macroscopic abnormality.

\section{DISCUSSION}

In mice with 12 and 24 hours of Allethrin exposure, there were failure in foetal development, as indicated by the presence of black spots on the uterus, namely foetal resorption. Foetal resorption is one proof of teratogenic properties of a substance. When the dose in embryotoxic is higher, the response will be higher as well such as inhibition of growth, malformation, and intrauterine foetal death and resorption. The exposure during growth can occur either in a direct way or through the mother, and it can cause stillbirth and some congenital abnormalities due to toxic effects on central nerves. An effect of lighter exposure has appeared in adults, namely cognitive impairment. Toxic exposure of this substance to infants, pregnant women, and breastfeeding mothers was caused by individuals who were inside a house for a longer time so that they received continuous exposure. ${ }^{5}$ Allethrin can cross the blood-brain barrier (BBB), so it can postpone maturity of the BBB and also produce some biochemical changes related to health risks especially in the early years of life. ${ }^{4}$

The administration of allethrin inhalation with dose 12 hours and 24 hours significantly damage mice's kidney and liver microscopically. The histological study of liver showed necrosis of the portal area, especially hydropic degeneration in lobules and inflammatory cell infiltration, as well as fibrosis starting at the portal area which caused sinusoids to expand at longer exposures of Allethrin. Necrotic characteristics were mainly found in higher duration of inhaling groups ( $3 \mathrm{~h}$ and $2 \mathrm{~h}$ ), probably because Allethrin induced toxicity on cell membranes. Necrotic cell death characteristically affects large fields of the tissue rather than a single cell and induces to release of cytoplasmic contents into the surrounding cellular environment leading to trigger inflammatory cells to be accumulated. Histological observation of hepatic tissue also reveals the degeneration of hepatocytes in such a 
way, affecting a single cell or small area of tissue without recruiting inflammatory cells (a critical feature of apoptotic cells). Histological study of hepatic tissue shows apoptosis mediating damage of hepatocytes along with severe forms of the necrosis. Infiltration of inflammatory cells was also observed in hepatic tissue. ${ }^{19}$

Histopathology slide found necrosis and degeneration especially hydropic degeneration and infiltration in lymphocyte and erythrocyte at the longer exposures in the microscopic description of mice's kidneys. A previous study about pyrethroids-containing insecticidemosquito coils found that there were abnormal histopathological features in forms of vascular degeneration and necrosis of hepatocytes, cardiac muscle degeneration, and necrosis in the glomerulus and renal tubules, meningitis, neuronophagia, demyelination, and exudative pneumonia. ${ }^{20}$ Histopathological changes in the kidneys occurred in glomerulus, tubules, and interstitials. The changes found in the glomerulus were vascular degeneration, apoptosis, protein deposits in the lumen, and dilatation of the tubular lumen. Hydropic degeneration found in the tubular epithelium. A use of high dose macroscopically showed a pale kidney. ${ }^{20}$

This study found an excessive aggressiveness in mice. This is allegedly due to Allethrin that can follow an oxidation degradation pathway and form free radicals and disruption of ion homeostasis. ${ }^{4,9}$ These free radicals lead to DNA damage and some health effects on the population of mice. Allethrin exposure can cause gene damage and oxidative stress in Swiss Albino mice. ${ }^{9}$ A study on mouse brain showed that pyrethroids could interact with neurotransmitters in the brain and could lead to neurobehavioral disorders that could occur in children and adults. ${ }^{4} \mathrm{~A}$ previous study that reported uses of Allethrin in mosquito coils and liquid mosquito repellent showed an increase of a blood flow to a blood-brain barrier and some biochemical changes in children. ${ }^{21}$ Allethrin is a sort of neurotoxin, acting on the peripheral and central nervous systems by changing the kinetics of voltage-sensitive sodium channel, triggering to increase sodium permeability across the channel and paralysis of insect's organs. ${ }^{19}$ Allethrin is membrane active material, which acts upon membrane phospholipids, raises membrane fluidity, and leads to leaking out cellular enzymes in the extracellular matrix. Finally, it expands transaminases movement in the blood. ${ }^{19}$

This study has not already discussed involvement of mice's brain, which can be used for further study to see clinical implications of motor and cognitive disorders that may occur. The hystomorfological features in mice's foetuses that experienced prematurity has not been observed yet in this study, and it is suggested for further study. Further study is needed with different exposure time and observation to other organs, especially the brain, to see a neurotoxic effect.

\section{CONCLUSION}

D-Allethrin inhalation exposure pathways in electric mosquito repellent causes necrosis of the portal area, hydropic degeneration in lobules and inflammatory cell infiltration, and liver fibrosis in female pregnant mice of Balb/c strain. In the kidneys, there was necrosis and degeneration, especially hydropic degeneration, and infiltration of lymphocytes and erythrocytes. In pregnant mice with 12 and 24 hours of exposure, there was a failure in foetal development and prematurity.

\section{CONFLICT OF INTEREST}

There is no conflict of interest in this study.

\section{ACKNOWLEDGEMENT}

The author would like to thank to the Research Grant of PHK-PKPD Universitas Diponegoro and the laboratory staff of Universitas Negeri Semarang for assistance of this study.

\section{REFERENCES}

1. Zhang R. Global dynamic analysis of a model for vector-borne diseases on bipartite networks. Physica A. 2020;545:123813.

2. Kemenkes. Profile kesehatan indonesia tahun 2017. Ministry of Health Indonesia. 2018. p:107-108. 
3. Li H, Lydy MJ, You J. Pyrethroids in indoor air during application of various mosquito repellents: Occurrence, dissipation and potential exposure risk. Chemosphere. 2016;144:2427-35.

4. Naz M, Rehman N, Nazam Ansari M, Kamal M, Ganaie MA, Awaad AS, et al. Comparative study of subchronic toxicities of mosquito repellents (coils, mats and liquids) on vital organs in Swiss albino mice. Saudi Pharmaceutical Journal. 2019;27(3):348-53.

5. Viel J-F, Warembourg C, Le Maner-Idrissi G, Lacroix A, Limon G, Rouget F, et al. Pyrethroid insecticide exposure and cognitive developmental disabilities in children: The PELAGIE mother-child cohort. Environment International. 2015;82(3):69-75.

6. Vesin A, Glorennec P, Le Bot B, Wortham H, Bonvallot N, Quivet E. Transfluthrin indoor air concentration and inhalation exposure during application of electric vaporizers. Environment International. 2013;60:1-6.

7. Tang W, Wang D, Wang J, Wu Z, Li L, Huang $M$, et al. Pyrethroid pesticide residues in the global environment: An overview. Chemosphere. 2018;191(308):990-1007.

8. Deziel NC, Colt JS, Kent EE, Gunier RB, Reynolds P, Booth B, et al. Associations between self-reported pest treatments and pesticide concentrations in carpet dust. Environmental Health. 2015;14(1):1-11.

9. As A, Axonic P, Insecticide E, As A, Inhibitor E, Glucuronyl OF, et al. Allerthrins as pyrethroid axonic excitoxin insecticide acts as an enzyme inhibitor of glucuronyl transferase with microsomal cytochrome P450 enzymes and depolarization of action po-tential. World Journal of Pharmaceutical Research. 2017;6(3):1044-54.

10. Chedik L, Bruyere A, Le Vee M, Stieger B, Denizot C, Parmentier Y, et al. Inhibition of human drug transporter activities by the pyrethroid pesticides allethrin and tetramethrin. PLoS One. 2017;12(1):1-29.

11. Chen S, Gu S, Wang Y, Yao Y, Wang G, Jin $Y$, et al. Exposure to pyrethroid pesticides and the risk of childhood brain tumors in East China. Environmental Pollution. 2016;218:1128-34.
12. van Wendel de Joode B, Mora AM, Lindh $\mathrm{CH}$, Hernández-Bonilla D, Córdoba L, Wesseling $\mathrm{C}$, et al. Pesticide exposure and neurodevelopment in children aged 6-9 years from Talamanca, Costa Rica. Cortex. 2016;85:137-50.

13. Wagner-Schuman M, Richardson J, Auinger P. Association of pyrethroid pesticide exposure with attention-deficit/hyperactivity disorder in a nationally representative sample of U.S. children. Environmental Health. 2015;14(6):470-1.

14. Csányi A, Hajagos-Tóth J, Kothencz A, Gaspar R, Ducza E. Effects of different antibiotics on the uterine contraction and the expression of aquaporin 5 in term pregnant rat. Reproductive Toxicology. 2018;81:6470.

15. Gholami M, Moallem SA, Afshar M, Amoueian S, Etemad L, Karimi G. Teratogenic effects of silymarin on mouse fetuses. Avicenna Journal of Phytomedicine. 2016;6(5):542-9.

16. Klaassen C. Toxicology. The Basic Science of Poisons. Vol. 7th edition, McGraw-Hill. 2008.

17. Da BL, Surana P, Kleiner DE, Heller T, Koh C. The Delta-4 fibrosis score (D4FS ): A novel fibrosis score in chronic hepatitis D. Antiviral Research. 2020;174:104691.

18. Burti S, Zotti A, Bonsembiante F, Mastellaro $G$. Research in veterinary science correlation between renal histopathology and renal ultrasound in dogs. Research in Veterinary Science. 2020;129:59-65.

19. Abdulla Al-Mamun M, Ataur Rahman M, Habibur Rahman M, Hoque KMF, Ferdousi Z, Matin MN, et al. Biochemical and histological alterations induced by the smoke of allethrin based mosquito coil on mice model. BMC Clinical Pathology. 2017;17(1):411.

20. Taiwo VO, Nwagbara ND, Suleiman R, Angbashim JE, Zarma MJ. Clinical signs and organ pathology in rats exposed to graded doses of pyrethroids-containing mosquito coil smoke and aerosolized insecticidal sprays. African Journal Biomedical Research. 2008;11(1):97-104. 
JKKI 2021;12(1):11-18

21. Narendra M, Gajothi GN, Begum SF, Sreekanth B. Mosquito repellent pyrethroid induced biochemical and biophysical changes in plasma and antioxidant status in human male volunteers exposed to long term allethrin and pral- lethrin inhalation. International Journal of Medicine and Pharmaceutical Sciences. 2014;4(6):1728. 